\title{
Changes in nearshore waves during the active sea/land breeze period off Vengurla, central west coast of India
}

\author{
M. M. Amrutha, V. Sanil Kumar, and J. Singh \\ Ocean Engineering Division, Council of Scientific \& Industrial Research-National Institute of Oceanography, \\ Dona Paula, Goa 403004 India \\ Correspondence to: V. Sanil Kumar (sanil@nio.org)
}

Published: 12 February 2016

\begin{abstract}
A unique feature observed in the tropical and subtropical coastal area is the diurnal sea-breeze/land-breeze cycle. We examined the nearshore waves at 5 and $15 \mathrm{~m}$ water depth during the active sea/land breeze period (JanuaryApril) in the year 2015 based on the data measured using the waverider buoys moored in the eastern Arabian sea off Vengurla, central west coast of India. Temporal variability of diurnal wave response is examined. Numerical model Delft3D is used to study the nearshore wave transformation. The wave height increased due to the sea breeze and reached its peak at $\sim$ 13:00 UTC at $15 \mathrm{~m}$ water depth, whereas the peak significant wave height is at 12:00 UTC at $5 \mathrm{~m}$ water depth. Due to the influence of the land/sea breeze system, the range of the peak wave period in 1 day varied up to $8 \mathrm{~s}$. Reduction in the wave height of wind-sea is around $20 \%$ and that of the swell is around $10 \%$ from 15 to $5 \mathrm{~m}$ water depth.
\end{abstract}

Keywords. Meteorology and atmospheric dynamics (waves and tides)

\section{Introduction}

Ocean surface gravity waves exist at the interface between the atmosphere and the ocean and account for more than half of the energy carried by all waves on the ocean surface (Kinsman, 1965). Generally, the ocean waves at any point will consist of the wind-seas and one or several swells propagating from distant sources (Soares, 1991). The different wave systems present at a point can be identified by analysing the wave spectrum (Hanson and Phillips, 2001). One of the largest challenges in wave dynamics studies is the lack of measured wave data. The North Indian Ocean being bounded to the north by the Asian continent leads to a unique seasonal reversal of the monsoon winds and associated waves (Anoop et al., 2015). Studies conducted in the eastern Arabian Sea (AS) indicate that due to the presence of swells and windseas, the wave spectrum is bimodal (Baba et al., 1989; Sanil Kumar et al., 2003; Vethamony et al., 2011). By analysing the wave data collected during the period 18-30 April 2005, at 2700 and $30 \mathrm{~m}$ water depth in the eastern AS, Sanil Kumar et al. (2007) observed that the conditions in the deep water are influenced by swell, whereas in the shallow water, the influence of wind-seas is dominating in most of the study period. The annual climatology of wind-seas and swells indicates that the waves in the North Indian Ocean are dominated by swells (Anoop et al., 2015). The contribution of swells in the measured data varied from 46 to $60 \%$ in the eastern AS (Sanil Kumar et al., 2014). Wave characteristics in the nearshore zone of Karwar, eastern AS was studied by Dora and Sanil Kumar (2015) and observed equal proportion of swells and wind-seas during February-May. When waves travel towards the coast, the wave characteristics change due to refraction, shoaling, diffraction, dissipation due to friction, dissipation due to percolation, breaking, additional growth due to the wind, wave-current interaction and wave-wave interactions. In the wide continental shelf under the swelldominated situation, dissipation of wave energy is mainly by bottom friction in the absence of local wind (Ardhuin et al., 2003). Aboobacker et al. (2013) reported that the reduction in significant wave height along the west coast of India between 25 and $15 \mathrm{~m}$ water depth off Goa and between 35 and $15 \mathrm{~m}$ depth off Ratnagiri is less than $10 \%$ and is higher $(22 \%)$ off Dwaraka between 30 and $15 \mathrm{~m}$. Off Ratnagiri, Aboobacker et al. (2013) observed that due to wave-bottom interaction and interaction of wind-sea with aligned swells, the swells attenuated. 
A general feature in tropical and subtropical coastal area is the diurnal sea/land breeze system (Miller et al., 2003). Pattiaratchi et al. (1997) linked increased wave energy to sea/land breeze forcing off the Australian coast. Due to the sea breeze, diurnal variation in wave parameters are reported in the eastern AS (Neetu et al., 2006; Vethamony et al., 2011; Glejin et al., 2013; Sanil Kumar and Anjali, 2015). Gunson and Symonds (2014) reported that local wave growth is duration limited during the sea breeze cycle and the wave growth is limited by fetch during the land breeze period. Along the eastern AS, March-April are the months during which transition from northeast monsoon (November-February) to the much stronger winds of the southwest monsoon (JuneSeptember) occurs (Neetu et al., 2006). Aparna et al. (2005) through analysis of Quickscat scatterometry demonstrated that along the central west coast of India, sea breezes can extend up to $100 \mathrm{~km}$ offshore.

The nearshore region of the eastern AS up to $\sim 10 \mathrm{~km}$ from the coast is comprised of intense fishing zones with use of mechanized boats and this area is also extensively used for tourism-related activities. Therefore, it is important to understand the changes in wave parameters during the active land/sea breeze system in the nearshore region. In this paper, we examine the changes in the characteristics of waves while propagating from 15 to $5 \mathrm{~m}$ water depth during JanuaryApril 2015 in the eastern AS. Since the wave conditions in the eastern Arabian Sea are complex due to the presence of swells arriving from different parts of the Indian Ocean and the wind-seas, we have also studied the variations in wave spectra due to the sea/land breeze. The paper is structured as follows. Section 2 contains the description of study area along with data and methodology used in the study. Section 3 contains a discussion of the results, and Sect. 4 summarizes the conclusions.

\section{Methods}

\subsection{Study region}

The study location is off Vengurla in the eastern AS. The wave buoy at $15 \mathrm{~m}$ water depth was moored at latitude $15.842^{\circ} \mathrm{N}$ and longitude $73.563^{\circ} \mathrm{E}$ and the wave buoy at $5 \mathrm{~m}$ water depth was at $15.844^{\circ} \mathrm{N} ; 73.625^{\circ} \mathrm{E}$ (Fig. 1). The buoy location at $15 \mathrm{~m}$ water depth is selected in such a way that the area is directly exposed to waves coming from the Indian Ocean and all parts of the Arabian Sea. The study area is exposed to open ocean waves from northwest to south, and the nearest landmass is $\sim 1500 \mathrm{~km}$ in the northwest, $\sim 2000 \mathrm{~km}$ in the west, $\sim 4000 \mathrm{~km}$ southwest and $\sim 9000 \mathrm{~km}$ in the south. Since the location is not deep water, the swell characteristics will be significantly influenced by bathymetry. The distance between the buoy locations at 15 and $5 \mathrm{~m}$ water depth is $6.64 \mathrm{~km}$ and the $5 \mathrm{~m}$ buoy is $0.44 \mathrm{~km}$ from the coastline. Headlands are present at $1.4 \mathrm{~km}$ north of the nearshore

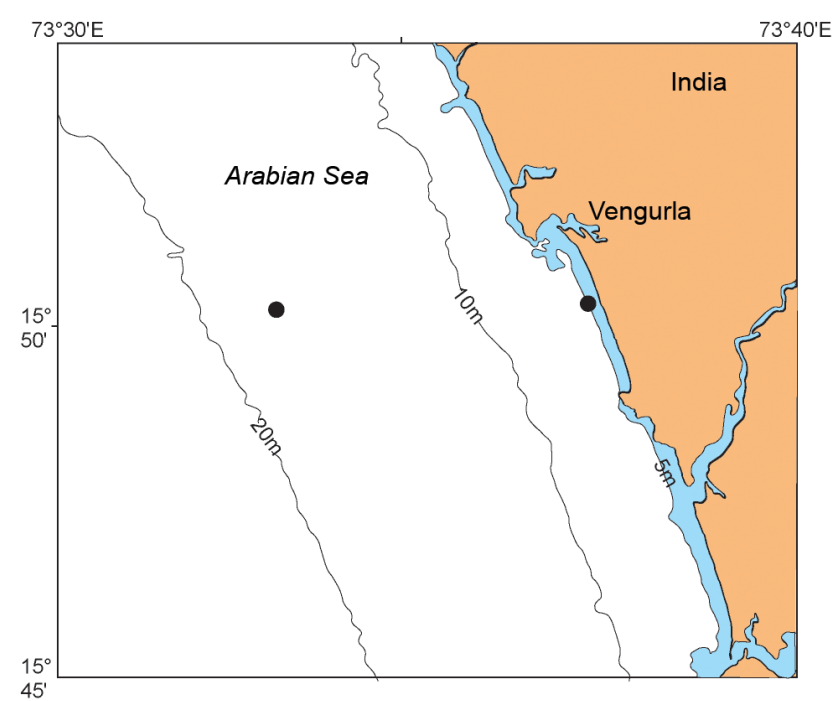

Figure 1. Location of the study area. The dark circles show the location of the waverider buoys at 15 and $5 \mathrm{~m}$ water depth.

buoy and $3.4 \mathrm{~km}$ south. The climate over the AS is dynamic due to seasonally reversing monsoon winds (Sanil Kumar et al., 2012). Wave characteristics of the study area before, during and after the onset of the Indian summer monsoon of 2014 were reported by Amrutha et al. (2015). In the study area, the highest $(\sim 2 \mathrm{~m})$ seasonal average significant wave height $\left(H_{\mathrm{m} 0}\right)$ is during the monsoon period (JuneSeptember), and the annual average $H_{\mathrm{m} 0}$ is $\sim 1 \mathrm{~m}$ (Amrutha et al., 2015). Swells from the Southern Ocean are present in the eastern AS during the non-monsoon period (Glejin et al., 2013). The tides along the study region are predominantly semi-diurnal and mixed. During the spring tide, the tidal range at Vengurla is $\sim 2.3 \mathrm{~m}$ and during the neap tide it is $\sim 1.3 \mathrm{~m}$.

\subsection{Data and methodology}

\subsubsection{Wave data}

Wave data measured at two locations using the Datawell directional waverider buoys from 1 January to 30 April 2015 are used in the study. Wave data collected at Ratnagiri, $130 \mathrm{~km}$ north of the buoy location at Vengurla, using the Datawell directional waverider buoy are also used for comparison of the study results. Auto- and cross-spectral densities of the vertical (heave) and two translational motions (north-south and east-west) of the buoy are estimated. The Maximum Entropy Method (MEM) is used to estimate the directional spectra at the buoy locations. The significant wave height $\left(H_{\mathrm{m} 0}\right)$, the peak wave period $\left(T_{\mathrm{p}}\right)$ and the mean wave period $\left(T_{\mathrm{m} 02}\right)$ are obtained from the wave spectrum. Based on circular moments, the mean wave direction $\left(D_{\mathrm{m}}\right)$ corresponding to the spectral peak frequency $\left(f_{\mathrm{p}}\right)$ is estimated following Kuik et al. (1988). The data analysis proce- 
dure is similar to that followed in Sanil Kumar et al. (2014). Nautical convection is followed to represent directions $\left(0^{\circ}\right.$ is for waves coming from the north). From the measured wave data, the swells and wind-seas are separated through a 1-D separation algorithm proposed by Portilla et al. (2009) based on the assumption that the energy of the swell at the peak frequency cannot be higher than the value of a PM spectrum (Pierson and Moskowitz, 1964) for the same peak frequency.

\subsubsection{Wind data}

Since no measured wind data are available for the study location, to analyse the wind pattern, the atmospheric reanalysis product of the ECMWF (European Centre for MediumRange Weather Forecasts) known as ERA-Interim (Dee et al., 2011) is used. ERA-Interim is the global reanalysis product of ECMWF available from 1979 onwards. The zonal and meridional components of the wind speed in $6 \mathrm{~h}$ intervals at a resolution of $0.25^{\circ} \times 0.25^{\circ}$ is used.

\subsubsection{Wave transformation model}

We used the Delft3D-wave module (Delft Hydraulics, 2011) developed by WL|Delft Hydraulics to quantify the change in wave height from 15 to $5 \mathrm{~m}$ water depth. This model is a slightly adapted version of the SWAN model (Booij et al., 1999), which is capable of simulating interactions and transformations of waves propagating through space: shoaling, refraction due to bottom and current variations, blocking and reflections due to opposing currents, transmission/blockage through/by obstacles, effects of wind, white capping, bottom friction, non-linear wave-wave interactions and depthinduced wave breaking. The formulation of Delft3D-wave is based on the spectral wave action balance equation and is fully spectral (in all directions and frequencies). The options allow control of fundamental physical processes in the model, like wave generation, dissipation and interaction. The wave computations in Delft3D-wave are stable due to the fully implicit schemes that have been implemented. In the Delft3D-wave module, the governing equation of wave transformation is based on action balance spectrum, in geographical space (Ris et al., 1998). The energy dissipation in SWAN is due to white-capping (mainly in deep water), bottom friction and depth-induced wave breaking (mainly in shallow water). Energy transformation between waves is by non-linear interactions; triad wave-wave interactions play a major role in shallow water, whereas quadruplet wave-wave interactions are important in deep water (Ris et al., 1998). The bathymetry of the study area is obtained by merging the nearshore measured bathymetry data with a digitized naval hydrographic chart No. 257 (NHO, 2004). Since there is no restriction for the model on the grid spacing, the selected domain was divided into a rectangular $405 \times 500$ grid with a grid spacing of $28.24 \mathrm{~m}$ along both $x$ and $y$ direction. Grid generation was done using "rgfgrid" of the Delft3D-wave module. The $H_{\mathrm{m} 0}, T_{\mathrm{p}}$ and $D_{\mathrm{m}}$ measured at $15 \mathrm{~m}$ water depth were used as the input wave parameters to the model. The offshore boundary was taken at $15 \mathrm{~m}$ water depth since the measured wave data were at this depth. The model has three types of boundary: (i) lateral boundaries at the north and south, (ii) an open boundary in the west where the waves with given height, period and direction propagate into the model area, and (iii) a closed boundary in the east (land). Input at the boundary is taken as a fully spectral approach in the model. The spectral resolution consists of 24 intervals from $0.05-1 \mathrm{~Hz}$ on a logarithmic scale, direction binned into 36 intervals of $10^{\circ}$ each. A time step of 30 min was selected owing to input data availability. To simulate the wave dissipation in shallow water, the depth-induced breaking model of Battjes and Janssen (1978) is used in the Delft3D-wave module. The parametrization of this model requires inputs of the depth-induced breaking alpha and gamma parameters. The alpha parameter which controls the rate of dissipation is taken as 1 , whereas the gamma parameter which controls the ratio of wave height to water depth at which wave breaking occurs is taken as 0.73 . The bottom friction coefficient value used in the study is 0.08 (Hasselmann et al., 1973).

\section{Results and discussion}

\subsection{Bulk wave parameters}

Semedo et al. (2011) observed that the global wave field is dominated by swell waves with the swell energy portion of total wave energy greater than $65 \%$ almost everywhere across the World Ocean. The present study shows that during the active sea/land breeze period, the swell energy portion is less. The waves at $15 \mathrm{~m}$ water depth consists of $58 \%$ windsea generated by local winds and $42 \%$ swells propagating from distant storms. At $5 \mathrm{~m}$ water depth, the wind-sea is reduced to $48 \%$ (Table 1). During the same period, at $13 \mathrm{~m}$ water depth off Ratnagiri, larger contribution (67\%) wind-sea is observed. Wave characteristics such as wave height and wave period are often used to describe the overall wave field. $H_{\mathrm{m} 0}$ gives an estimate of the total energy, including all spectral peaks. Waves in this area during February-April tend to be smaller with $H_{\mathrm{m} 0}$ below $1 \mathrm{~m}$ during most of the time. The monthly average $H_{\mathrm{m} 0}$ at $15 \mathrm{~m}$ water depth is $0.55,0.52,0.63$ and $0.62 \mathrm{~m}$ during January-April and the same at Ratnagiri in 2015 is $0.70,0.67,0.74$ and $0.70 \mathrm{~m}$ and was $0.56,0.63,0.70$ and $0.76 \mathrm{~m}$ during 2011 (Amrutha and Sanil Kumar, 2015). The spatial variation in $H_{\mathrm{s}}$ between Ratnagiri and Vengurla is $12-27 \%$. Anoop et al. (2014) showed that $270 \mathrm{~km}$ along the central west coast of India, between Karwar and Ratnagiri, the variation of $H_{\mathrm{s}}$ between the locations was equal to or slightly greater than $20 \%$ during non-monsoon season, whereas it was less than $10 \%$ during the monsoon season. In the present study, the measured data indicate that $H_{\mathrm{m} 0}$ at $5 \mathrm{~m}$ water depth is $13 \%$ less than that at $15 \mathrm{~m}$ water depth 
Table 1. Average value of wave parameters at 15 and $5 \mathrm{~m}$ water depth in different months.

\begin{tabular}{lrr|rr|rr|r|rr}
\hline & \multicolumn{2}{c}{ January } & \multicolumn{2}{c|}{ February } & \multicolumn{2}{c|}{ March } & \multicolumn{2}{c}{ April } \\
\cline { 2 - 9 } & $15 \mathrm{~m}$ & $5 \mathrm{~m}$ & $15 \mathrm{~m}$ & $5 \mathrm{~m}$ & $15 \mathrm{~m}$ & $5 \mathrm{~m}$ & $15 \mathrm{~m}$ & $5 \mathrm{~m}$ \\
\hline$H_{\mathrm{m} 0}(\mathrm{~m})$ & 0.55 & 0.46 & 0.52 & 0.45 & 0.63 & 0.56 & 0.62 & 0.55 \\
$H_{\max }(\mathrm{m})$ & 0.82 & 0.70 & 0.80 & 0.66 & 0.95 & 0.86 & 0.93 & 0.84 \\
$T_{\mathrm{m} 02}(\mathrm{~s})$ & 4.6 & 5.1 & 4.2 & 4.4 & 4.8 & 5.1 & 4.5 & 4.8 \\
$T_{\mathrm{m} 01}(\mathrm{~s})$ & 5.4 & 6.2 & 4.8 & 5.2 & 5.8 & 6.3 & 5.3 & 5.8 \\
$T_{\mathrm{p}}(\mathrm{s})$ & 12.2 & 13.6 & 10.0 & 12.1 & 12.6 & 13.3 & 12.9 & 13.4 \\
$T_{H_{\text {max }}}(\mathrm{s})$ & 8.8 & 10.5 & 7.2 & 8.5 & 9.6 & 10.8 & 9.5 & 10.5 \\
$D_{\mathrm{m}}($ deg$)$ & 240 & 231 & 253 & 235 & 231 & 231 & 226 & 229 \\
Swell (\%) & 39 & 53 & 32 & 41 & 49 & 58 & 47 & 55 \\
Wind-sea (\%) & 61 & 47 & 68 & 59 & 51 & 42 & 53 & 44 \\
\hline
\end{tabular}

(Fig. 2a). The reduction in $H_{\mathrm{m} 0}$ of wind-sea is around $20 \%$ and that of the swell is around $10 \%$ (Fig. 3a and b). The wave length of the wind-sea at $15 \mathrm{~m}$ water depth varied from 8 to 39 with a mean value of $19 \mathrm{~m}$ and hence the bottom friction mainly acts on the swells at this location. But the reduction in $H_{\mathrm{m} 0}$ at $5 \mathrm{~m}$ water depth compared to $15 \mathrm{~m}$ is mainly due to the dissipation of wind-sea and hence the average value of the mean wave period is higher $(\sim 4.9 \mathrm{~s})$ at $5 \mathrm{~m}$ than that ( $\sim 4.5 \mathrm{~s}$ ) at $15 \mathrm{~m}$ water depth (Fig. $2 \mathrm{~b}$ ).

Without considering the wind, the wave transformation is carried out to know the dissipation in the nearshore area and it is observed that $27 \%$ of the wind-sea $H_{\mathrm{m} 0}$ and $16 \%$ of the swell $H_{\mathrm{m} 0}$ gets dissipated in the nearshore (Fig. $3 \mathrm{c}$ and d). By including the wind, the estimated $H_{\mathrm{m} 0}$ at $5 \mathrm{~m}$ water depth using the wave transformation model is within $15 \%$ of the measured value (Fig. 3f). The root mean square error indicates that major errors in the hindcast swell $H_{\mathrm{m} 0}$ amount to less than $0.06 \mathrm{~m}$ with bias of $0.03 \mathrm{~m}$ and the scatter index $(\sim 0.11)$ indicates low dispersion of the data. But the bias $(\sim 0.11 \mathrm{~m})$ and scatter index $(\sim 0.16)$ are high for the windsea. The spatial distribution of average $H_{\mathrm{m} 0}$ in April 2015 between 15 and $5 \mathrm{~m}$ water depth based on the numerical model is shown in Fig. 4 along with the model domain. The numerical model tends to underestimate $H_{\mathrm{m} 0}$, which could be due to the low-resolution wind data used in the study. Also, in particular, the short wind waves do not propagate in the same direction as swell, and the shallow buoy ( $5 \mathrm{~m}$ water depth) cannot be aligned with the first one ( $15 \mathrm{~m}$ water depth) on the wave rays. However, due to the quasi-rectilinear shape of the coastline and bathymetry and assumption that the waves in the $15 \mathrm{~m}$ depth contour for $20 \mathrm{~km}$ along the coast will not vary significantly, this point was able to be overcome, resulting in good correlation with the measured $H_{\mathrm{m} 0}$.

The peak wave period indicates that waves are predominantly swell dominated with monthly average $T_{\mathrm{p}}$ ranging from 10 to $13 \mathrm{~s}$ at $15 \mathrm{~m}$ water depth and from 12 to $14 \mathrm{~s}$ at $5 \mathrm{~m}$ water depth (Table 1 ). The wave-wave interactions transfer wave energy from the spectral peak both to lower frequencies, moving the peak frequency to lower values, and to

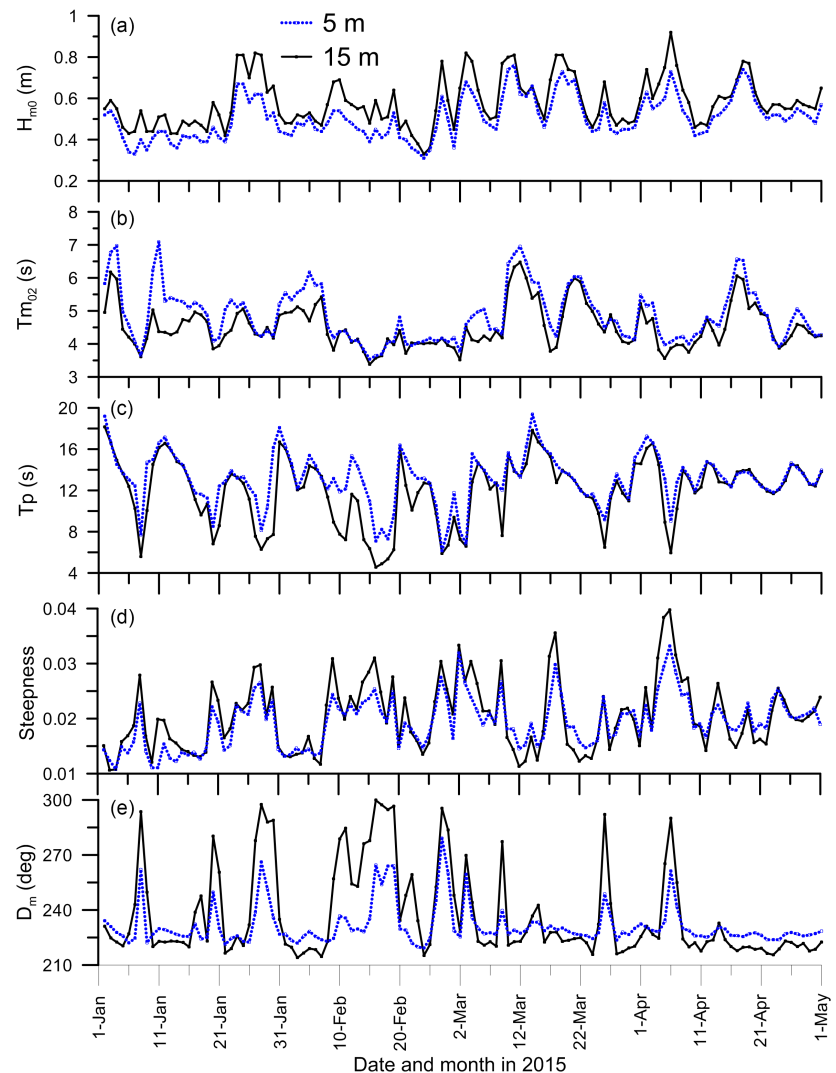

Figure 2. Time series plot of daily average wave parameters: (a) significant wave height $\left(H_{\mathrm{m} 0}\right)$, (b) mean wave period $\left(T_{\mathrm{m} 02}\right)$, (c) peak wave period $\left(T_{\mathrm{p}}\right),(\mathbf{d})$ wave steepness and (e) mean wave direction $\left(D_{\mathrm{m}}\right)$.

higher frequencies, where the energy is dissipated by whitecapping. Hence, the peak period is higher at $5 \mathrm{~m}$ water depth compared to $15 \mathrm{~m}$ water depth (Fig. 2c). The wave steepness $\left(H_{\mathrm{m} 0} / L\right.$, where $L$ is the wave length) is high at $15 \mathrm{~m}$ compared to $5 \mathrm{~m}$ water depth (Fig. 2d). Wind-seas due to the sea breeze from the northwest and the short-period swells by the Shamal events with peak period of 3-8 s are also observed 
Table 2. Average value of wave parameters of long-period (LP), intermediate-period (IP) and short-period (SP) waves at 15 and $5 \mathrm{~m}$ water depth in different months.

\begin{tabular}{lrr|rr|rr|rr}
\hline \multirow{2}{*}{ Wave parameter } & \multicolumn{2}{c|}{ January } & \multicolumn{2}{c|}{ February } & \multicolumn{2}{c|}{ March } & \multicolumn{2}{c}{ April } \\
\cline { 2 - 9 } & $15 \mathrm{~m}$ & $5 \mathrm{~m}$ & $15 \mathrm{~m}$ & $5 \mathrm{~m}$ & $15 \mathrm{~m}$ & $5 \mathrm{~m}$ & $15 \mathrm{~m}$ & $5 \mathrm{~m}$ \\
\hline$H_{\mathrm{m} 0} \mathrm{LP}(\mathrm{m})$ & 0.24 & 0.24 & 0.18 & 0.19 & 0.30 & 0.31 & 0.29 & 0.30 \\
$H_{\mathrm{m} 0}$ IP (m) & 0.28 & 0.24 & 0.24 & 0.21 & 0.32 & 0.29 & 0.30 & 0.28 \\
$H_{\mathrm{m} 0}$ SP (m) & 0.38 & 0.28 & 0.41 & 0.32 & 0.41 & 0.33 & 0.43 & 0.35 \\
$T_{\mathrm{m} 02} \mathrm{LP}(\mathrm{s})$ & 14.60 & 14.74 & 13.99 & 14.10 & 14.33 & 14.47 & 14.08 & 14.17 \\
$T_{\mathrm{m} 02}$ IP (s) & 7.89 & 8.23 & 8.25 & 8.59 & 8.40 & 8.71 & 8.57 & 8.88 \\
$T_{\mathrm{m} 02}$ SP (s) & 3.34 & 3.25 & 3.32 & 3.20 & 3.23 & 13.31 & 3.13 & 3.04 \\
LP (\%) & 22.75 & 32.00 & 16.09 & 22.41 & 26.47 & 33.34 & 24.67 & 31.27 \\
IP (\%) & 27.30 & 29.07 & 22.88 & 24.55 & 29.37 & 29.72 & 26.36 & 27.10 \\
SP (\%) & 49.92 & 38.95 & 61.03 & 53.03 & 44.17 & 36.91 & 48.97 & 41.63 \\
\hline
\end{tabular}
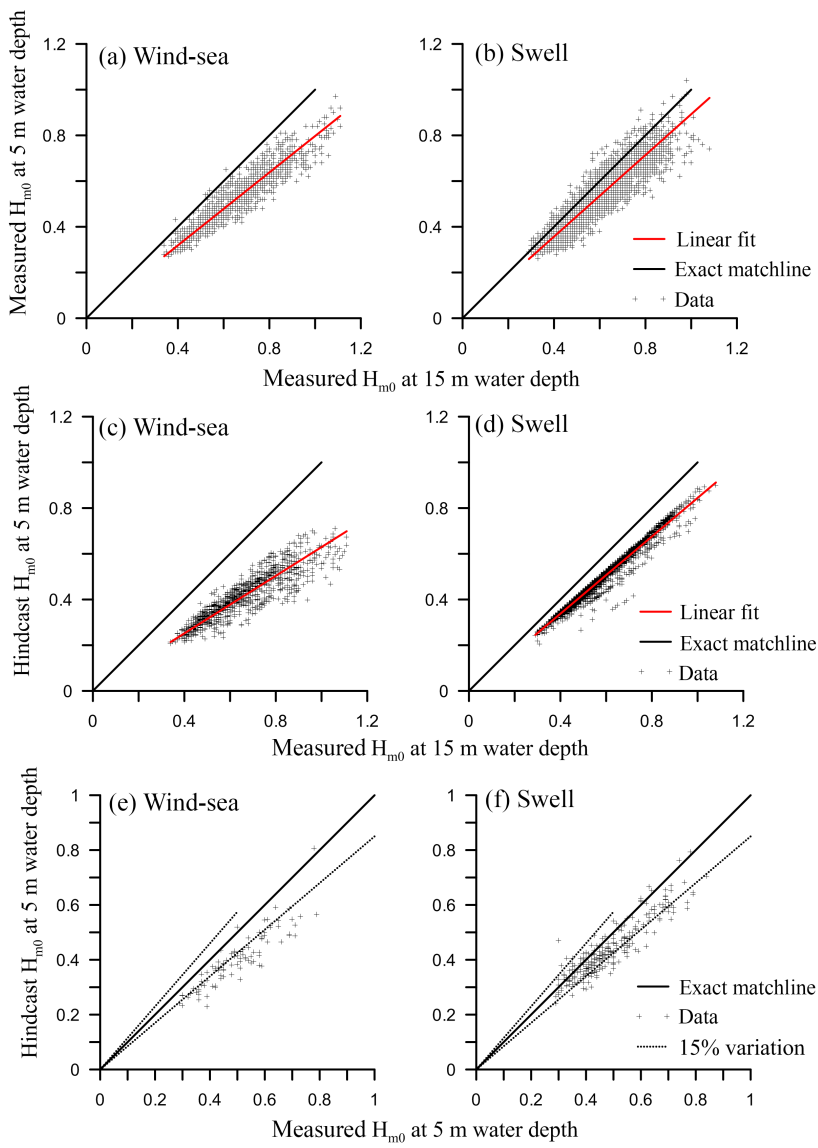

Figure 3. Scatter plot of measured $H_{\mathrm{m} 0}$ at 15 and $5 \mathrm{~m}$ water depth (a) for wind-sea and (b) for swell. (c) Scatter plot of hindcast $H_{\mathrm{m} 0}$ at $5 \mathrm{~m}$ with the measured value at $15 \mathrm{~m}$ water depth for wind-sea and (d) for swell. (e) Scatter plot of hindcast $H_{\mathrm{m} 0}$ at $5 \mathrm{~m}$ water depth with the measured data at $5 \mathrm{~m}$ water depth for wind-sea and (f) for swell.

(Fig. 2e). In the pre-monsoon period, Glejin et al. (2013) also reported the presence of northwest waves off Ratna-

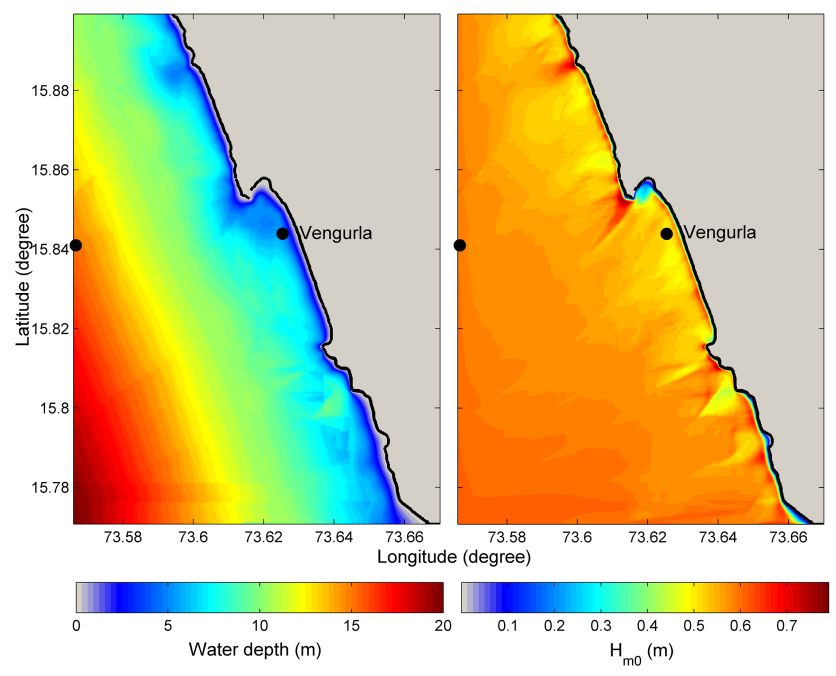

Figure 4. Left panel: the model domain and the bathymetry of the study area. Right panel: the spatial variation in average significant wave height in April 2015. The wave measurement locations are shown in dark circles.

giri, $130 \mathrm{~km}$ north of the Vengurla buoy location due to the Shamal events.

During the period of study, the monthly average contribution of short-period waves (period $<6 \mathrm{~s}$; dominated by local wind-seas) is $44-61 \%$ at $15 \mathrm{~m}$ water depth and is $37-53 \%$ at $5 \mathrm{~m}$ water depth, which indicates a reduction of shortperiod waves at $5 \mathrm{~m}$ water depth (Table 2). The contribution of short-period waves are maximum (53-61\%) in February. The contribution of long-period waves (period $>12 \mathrm{~s}$; resulting mainly from swell) is slightly higher $(\sim 29.8 \%)$ at $5 \mathrm{~m}$ water depth than at $15 \mathrm{~m}$ water depth $(\sim 22.5 \%)$ and the contributions of intermediate-period waves is similar $(\sim 27 \%)$ at both locations. Amrutha et al. (2015) showed that the average contribution of short-period waves at $15 \mathrm{~m}$ water depth at Vengurla is $43 \%$ before the onset of the monsoon in the year 2013. At Ratnagiri, the contribution of wind-seas is higher 


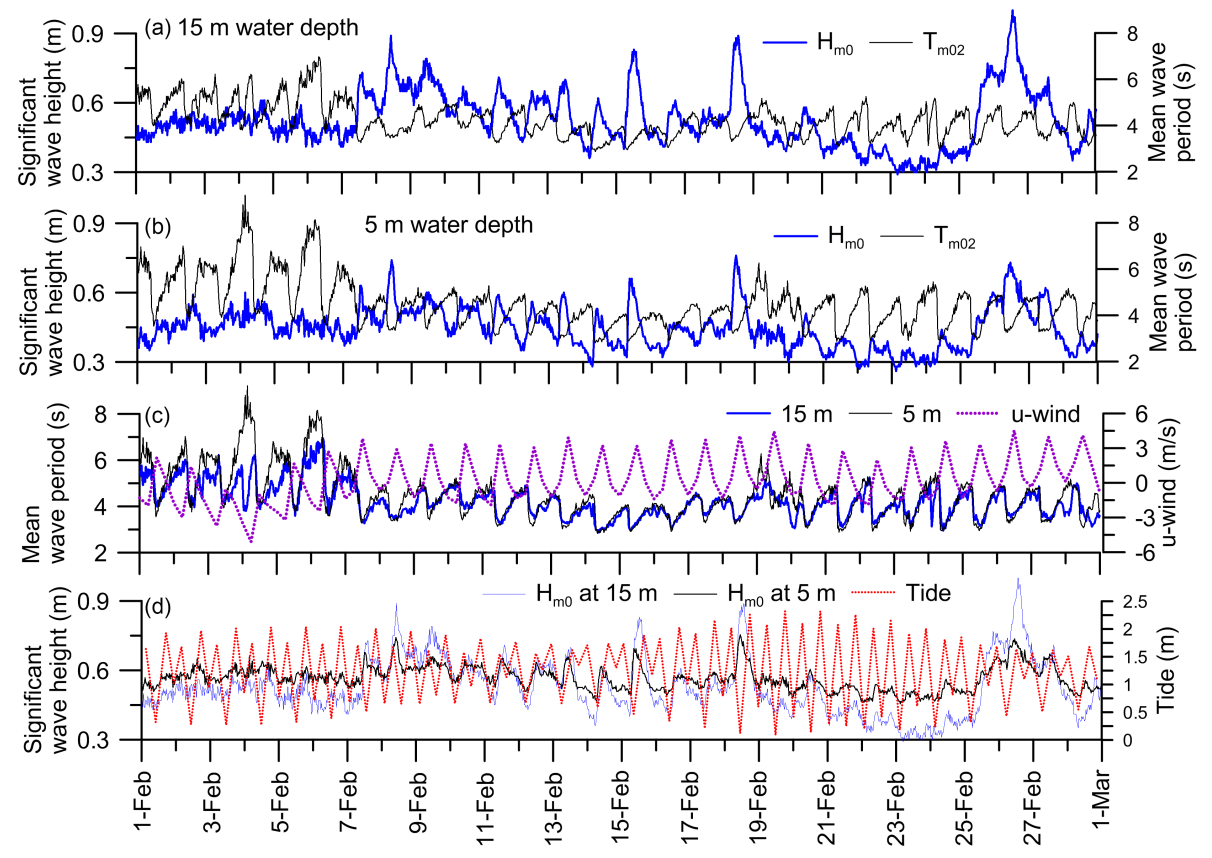

Figure 5. (a) Plot of significant wave height and mean wave period at $15 \mathrm{~m}$ water depth, (b) at $5 \mathrm{~m}$ water depth, (c) mean wave period at 15 and $5 \mathrm{~m}$ water depth and cross-shore wind speed and (d) significant wave height at 15 and $5 \mathrm{~m}$ water depth and the tide.

( $\sim 60 \%)$ compared to the locations at Vengurla ( $\sim 43$ and $51 \%)$.

The maximum wind speed ranges from 5 to $6 \mathrm{~m} \mathrm{~s}^{-1}$ from the southwest during the peak sea breeze period. The wave height and the wave periods (both the mean wave period and the peak wave period) show an inverse proportion (Fig. 5). Vethamony et al. (2011) showed that, off the Goa coast, the superimposition of northwest locally generated waves with pre-existing southwest swell leads to an increase in wave height. In the present study also, similar wave conditions are observed during January-April since the study area is within $50 \mathrm{~km}$ from the location considered in the study of Vethamony et al. (2011). Off Goa at $23 \mathrm{~m}$ water depth, during 1-15 April 1996, the wave spectral energy peaked around 18:00-20:00 LT (12:30-14:30 UTC) though the onset of the sea breeze is around 10:00 LT (04:30 UTC); maximum wind speed is observed at 15:00 LT (09:30 UTC) (Neetu et al., 2006). Along the west coast of India, the sea breeze starts around 05:30 UTC (11:00 LT), and it continues to blow in the northwest direction between 09:30 UTC (15:00 LT) and 12:30 UTC (18:00 LT) and after this, the wind speed gradually reduces (Vethamony et al., 2011). To have an idea of how the wave parameters in the study area vary with the sea breeze system, the hourly variation of $H_{\mathrm{m} 0}$ and $T_{\mathrm{m} 02}$ in different months are studied (Fig. 6). The present study shows similar diurnal variations in the $H_{\mathrm{m} 0}$ at 5 and $15 \mathrm{~m}$ water depth (Fig. 6). The average diurnal variation of $H_{\mathrm{m} 0}$ during January-April is $0.1 \mathrm{~m}$ with maximum range during March. After the onset of the sea breeze, the $H_{\mathrm{m} 0}$ increased and $T_{\mathrm{m} 02}$ decreased. In the peak sea breeze time, $H_{\mathrm{m} 0}$ in- creases by a factor of 1.5 and the peak period decreases from 12 to $5 \mathrm{~s}$. The wave height does not attain the maximum value at the same time in 15 and $5 \mathrm{~m}$ water depths, and there is a difference of up to $1 \mathrm{~h}$ in the time (Fig. 6). From the hourly variation of $H_{\mathrm{m} 0}$ and $T_{\mathrm{m} 02}$, it is observed that the wave field is energized by the sea breeze in the afternoon, and the wave height reaches maximum during 12:00-13:00 UTC (17:30-18:30 LT) at $15 \mathrm{~m}$ water depth and during 11:0012:00 UTC (16:30-17:30 LT) at $5 \mathrm{~m}$ water depth. In May 2005 , off the west coast of India, the wind-sea $H_{\mathrm{m} 0}$ is maximum between 18:00 and 21:00 LT (12:30 and 15:30 UTC) (Aboobacker et al., 2014). The diurnal variation in percentage of short-period waves, intermediate-period waves and long-period waves is also examined. Due to the sea breeze during January-April, the percentage of short-period waves increases from 15 to $26 \%$ at $5 \mathrm{~m}$ water depth and from 10 to $20 \%$ at $15 \mathrm{~m}$ water depth (Fig. 6). The variation in the percentage of intermediate-period waves at both the 15 and $5 \mathrm{~m}$ water depth is less than $15 \%$ and that of the long-period waves is less than $10 \%$. Even though the diurnal variation of the $H_{\mathrm{m} 0}$ is similar at 5 and $15 \mathrm{~m}$ water depth, the diurnal variation of the short-period waves are 10-20\% higher at $5 \mathrm{~m}$ water depth than at $15 \mathrm{~m}$ water depth.

In this study, the range of $H_{\mathrm{m} 0}$ (the difference between the maximum and the minimum value) in 1 day varied by up to $0.3 \mathrm{~m}$ (Fig. 7a) and the range of $T_{\mathrm{m} 02}$ in 1 day varied by up to $3 \mathrm{~s}$ (Fig. 7b). During this period, the range of the $T_{\mathrm{p}}$ in 1 day varied by up to $8 \mathrm{~s} \mathrm{(Fig.} \mathrm{7c).} \mathrm{The} \mathrm{large} \mathrm{variation} \mathrm{in} \mathrm{the} T_{\mathrm{m} 02}$ and the $T_{\mathrm{p}}$ in 1 day is due to the land breeze sea breeze system. During the land breeze period, long-period $\left(T_{\mathrm{p}}>10 \mathrm{~s}\right)$ 

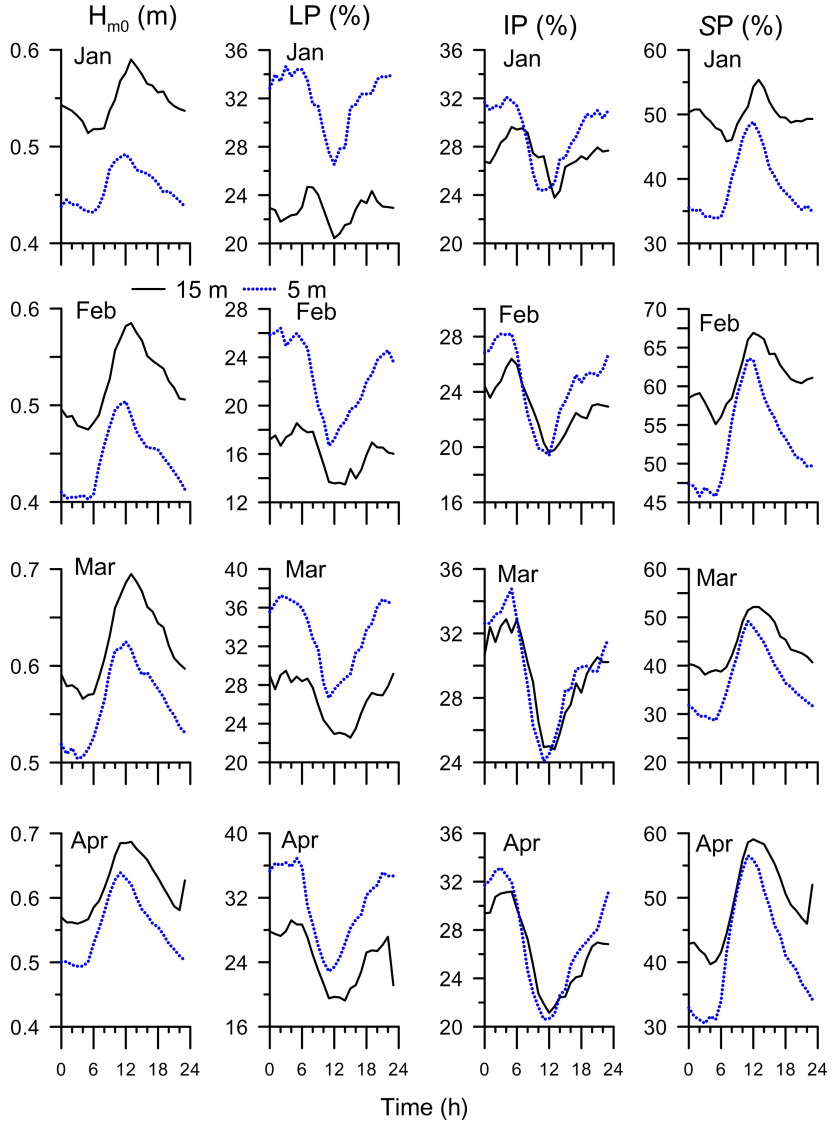

Figure 6. Variation in $1 / 2$ hourly averaged wave parameters; (a) significant wave height $\left(H_{\mathrm{m} 0}\right)$, (b) percentage of long-period (LP) waves, (c) percentage of intermediate period (IP) waves and (d) percentage of short-period (SP) waves.

swell is predominant, while during the sea breeze period, short-period $\left(T_{\mathrm{p}}<5 \mathrm{~s}\right)$ wind-seas are predominant, superimposed with swells. The low-frequency waves $(0.05-0.14 \mathrm{~Hz})$ during January-April are from 210 to $240^{\circ}$, which is similar to the observation of Sanil Kumar et al. (2014) for other locations along the central west coast of India. Due to the influence of land/sea breezes, the mean wave direction varied up to $80^{\circ}$ in a day (Fig. 7d). Before the sea breeze at 09:00 UTC, the swell and wind-sea at $15 \mathrm{~m}$ water depth are from $220^{\circ}$ and with the increase in sea breeze the wave direction gradually shifted to $320^{\circ}$ by 18:00 UTC. At $5 \mathrm{~m}$ water depth, the wave direction shifted from 220 to $300^{\circ}$ due to the sea breeze.

\subsection{Wave spectrum}

Wave spectral energy density provides more information than the bulk wave parameters, making it possible to distinguish between the distant and local waves. Sanil Kumar et al. (2014) have shown that even though the bulk wave parameters do not change significantly, there is large variation
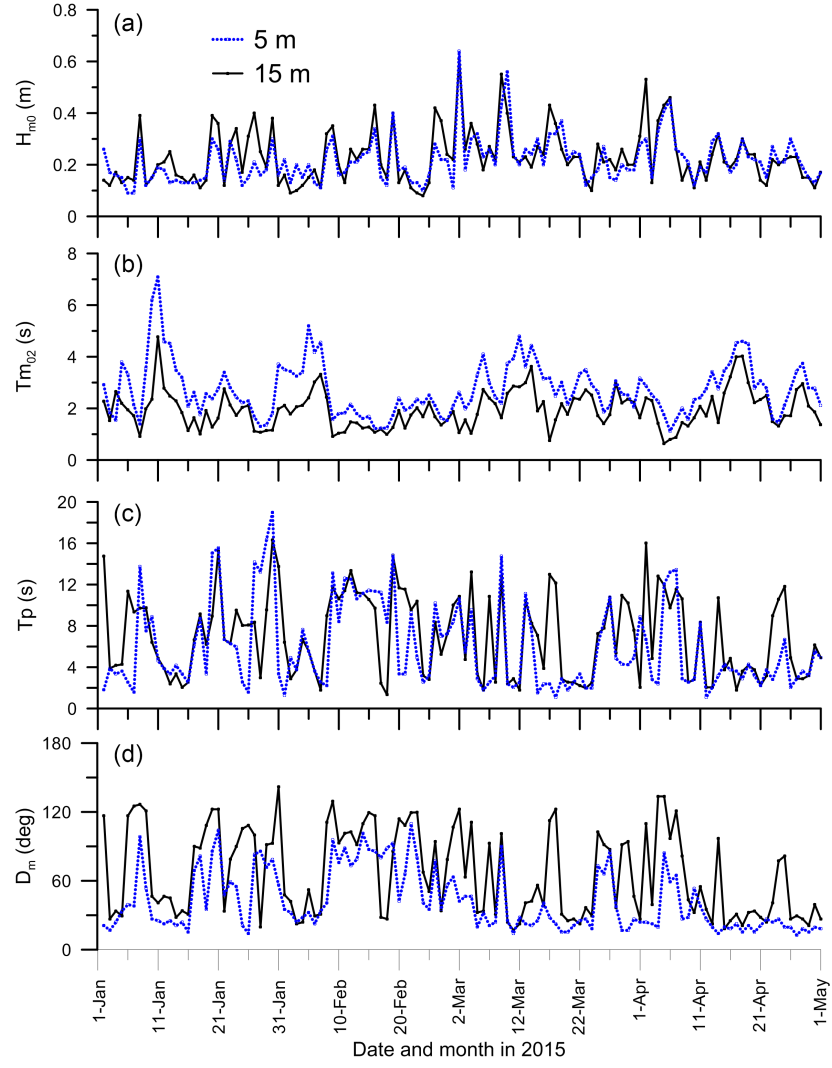

Figure 7. Time series plot showing the range of wave parameters in a day; (a) significant wave height $\left(H_{\mathrm{m} 0}\right)$, (b) mean wave period $\left(T_{\mathrm{m} 02}\right),(\mathbf{c})$ peak wave period $\left(T_{\mathrm{p}}\right)$ and $(\mathbf{d})$ mean wave direction $\left(D_{\mathrm{m}}\right)$.

in the wave spectrum within $350 \mathrm{~km}$ along the eastern AS. In the $350 \mathrm{~km}$ stretch along the eastern AS, double-peaked spectra observed were usually swell-dominated in the southern location (Honnavar, $220 \mathrm{~km}$ south of Vengurla), whereas in the northern location (Ratnagiri), the double-peaked spectra during January-May were usually sea-dominated, indicating the presence of strong local wind from the northwest (Sanil Kumar et al., 2014). In order to know the change in spectral components with time at 15 and $5 \mathrm{~m}$ water depth, the plots of wave spectral energy density in a frequencytime domain are analysed. The contour plots of spectral energy density are presented in a normalized scale since the maximum spectral energy density of each record varied from 0.04 to $5.11 \mathrm{~m}^{2} \mathrm{~Hz}^{-1}$ during the study period (Fig. 8). Each spectrum is normalized by dividing the wave spectral energy density by the maximum spectral energy density of the spectrum. Spectral energy is spread to higher frequencies $(>0.25 \mathrm{~Hz})$ and $26 \%$ of the total spectral energy is beyond $0.25 \mathrm{~Hz}$. At $15 \mathrm{~m}$ water depth, $66.6 \%$ of the wave spectra are multi-peaked and $78 \%$ of the total spectra are swell-dominated, whereas at $5 \mathrm{~m}$ water depth, $49.1 \%$ of the wave spectra are multi-peaked and $90 \%$ of the to- 
(a)

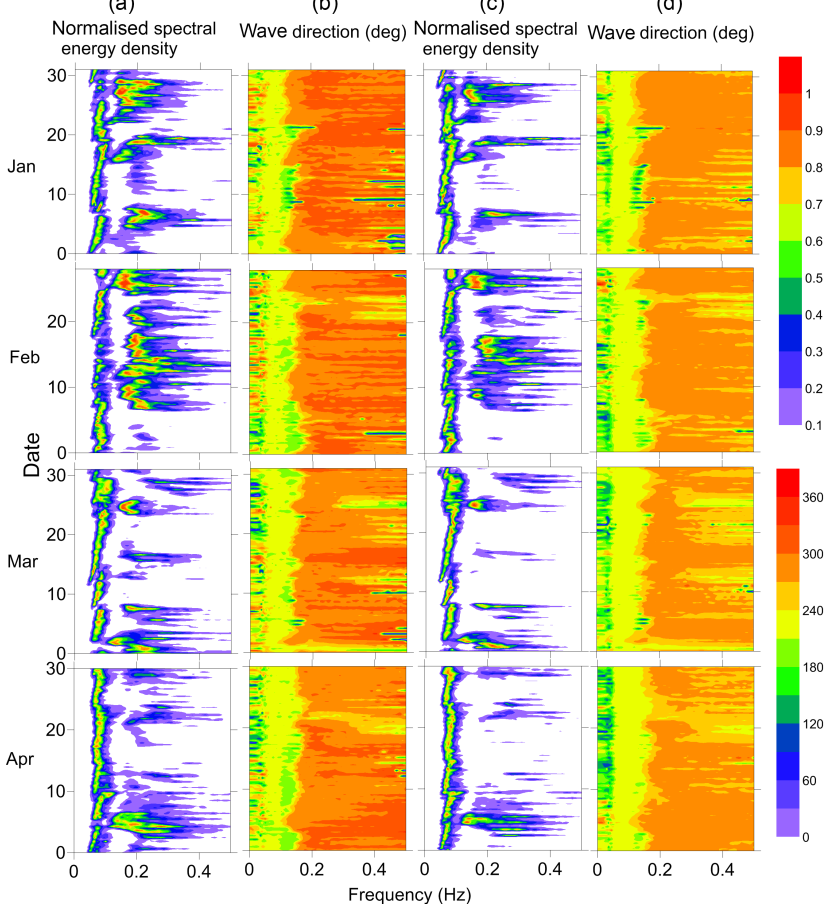

Figure 8. Plot of (a) normalized spectral energy density and (b) mean wave direction at $15 \mathrm{~m}$ water depth in different months, (c) normalized spectral energy density and (d) mean wave direction at $5 \mathrm{~m}$ water depth in different months.

tal spectra are swell-dominated. During the study period, long-period swells $\left(T_{\mathrm{p}} \sim 18 \mathrm{~s}\right)$ arrived in distinct trains lasting about 2 days (Fig. 8) and such episodes occurred six times. The study shows that with the interaction of windsea with long-period swells, the frequency of the peak wave energy gradually shifted towards high-frequency region and the pattern was similar at 15 and $5 \mathrm{~m}$ water depth (Fig. 8). Higher-frequency waves from the northwest also occurred apart from the trains of swells from southwest. During May 2009, Sanil Kumar et al. (2012) also observed the arrival of swells $\left(T_{\mathrm{p}}>10 \mathrm{~s}\right)$ in distinct trains lasting about 5 days off the west coast of India at locations 125 and $300 \mathrm{~km}$ south of Vengurla. The plot of the difference in spectral energy density at 15 and $5 \mathrm{~m}$ water depth with frequency in different months are presented in Fig. 9. Due to dissipation, the spectral energy density for frequency more than $0.1 \mathrm{~Hz}$ is less at $5 \mathrm{~m}$ compared to $15 \mathrm{~m}$ water depth (Fig. 9).

To study the wave directional characteristics at 15 and $5 \mathrm{~m}$ water depth, monthly averaged directional spectrum is estimated from the half-hourly data. Since in all months, the frequency bins over which the wave spectra estimated at halfhourly intervals are the same, from the half-hourly spectra, the monthly averaged spectrum is computed for a particular month by taking the average of the spectral energy density at the respective frequencies. The concept of using the monthly average directional spectrum is to identify the predominant
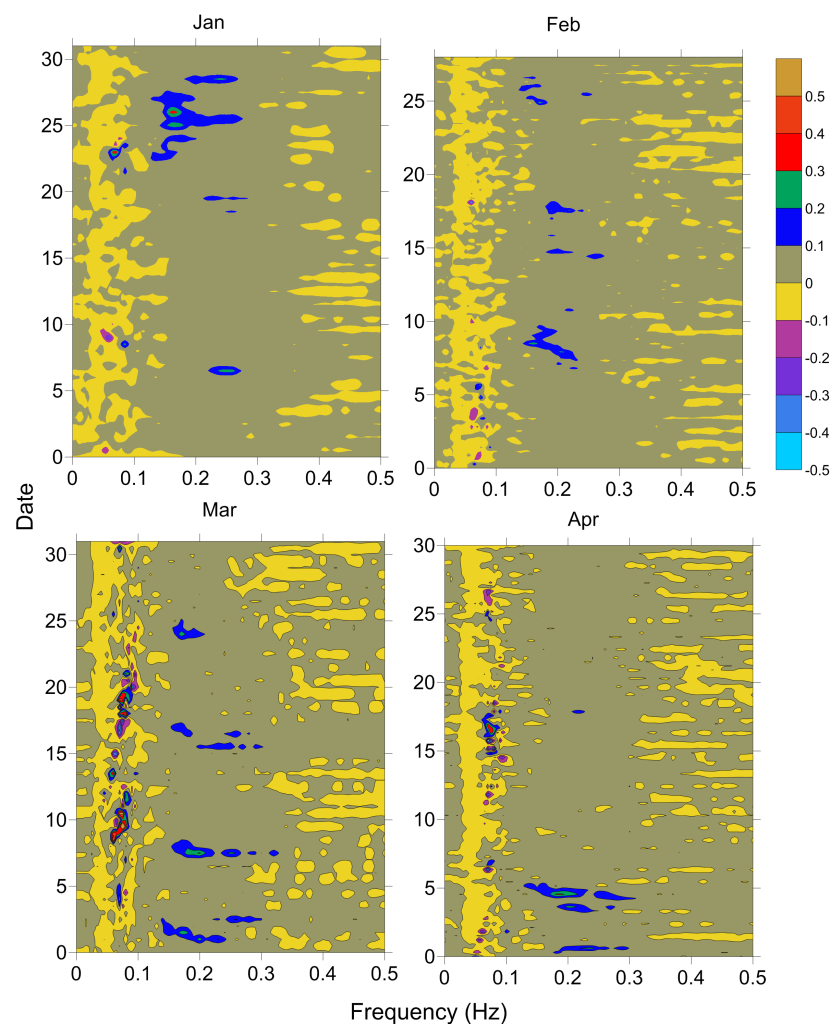

Figure 9. Plot of the difference in spectral energy density $\left(\mathrm{m}^{2} \mathrm{~Hz}^{-1}\right)$ with different frequency at $15 \mathrm{~m}$ water depth and $5 \mathrm{~m}$ water depth in different months.

frequency and direction for the particular month. Averaged directional wave spectrum at 15 and $5 \mathrm{~m}$ water depth shows fully separated double peaks with primary peak corresponding to the southwest swells and the secondary peak due to the northwest wind-sea (Fig. 10a and b). The spectral energy density at the spectral peaks is higher at $15 \mathrm{~m}$ than at $5 \mathrm{~m}$ water depth and hence the difference in spectral energy density is positive at the peaks (Fig. 10c).

Both the swell- and wind-sea-dominated spectra are observed in the study area and the mean wave spectrum during the study period also shows the co-existence of the swells and wind-seas identified in the monthly plots (Fig. 11a). The sharp peak in the low-frequency region corresponds to the swell and the secondary peak in the high-frequency region corresponds to the wind waves. The spectral energy density is almost similar for the swell part at both the 15 and $5 \mathrm{~m}$ water depth. However, at the wind-sea part, higher spectral energy density is observed at $15 \mathrm{~m}$ water depth than at $5 \mathrm{~m}$ (Fig. 11a). The mean wave spectrum is double-peaked and shows the predominant peak at $0.074 \mathrm{~Hz}$ (swell peak) both at 15 and $5 \mathrm{~m}$ water depth. However, the secondary peak (wind-sea peak) is at 0.174 (at $5 \mathrm{~m}$ water depth) and $0.187 \mathrm{~Hz}$ (at $15 \mathrm{~m}$ water depth) (Fig. 11a). We have checked the wave data collected at Ratnagiri during 1 January-30 April 2015 and found 


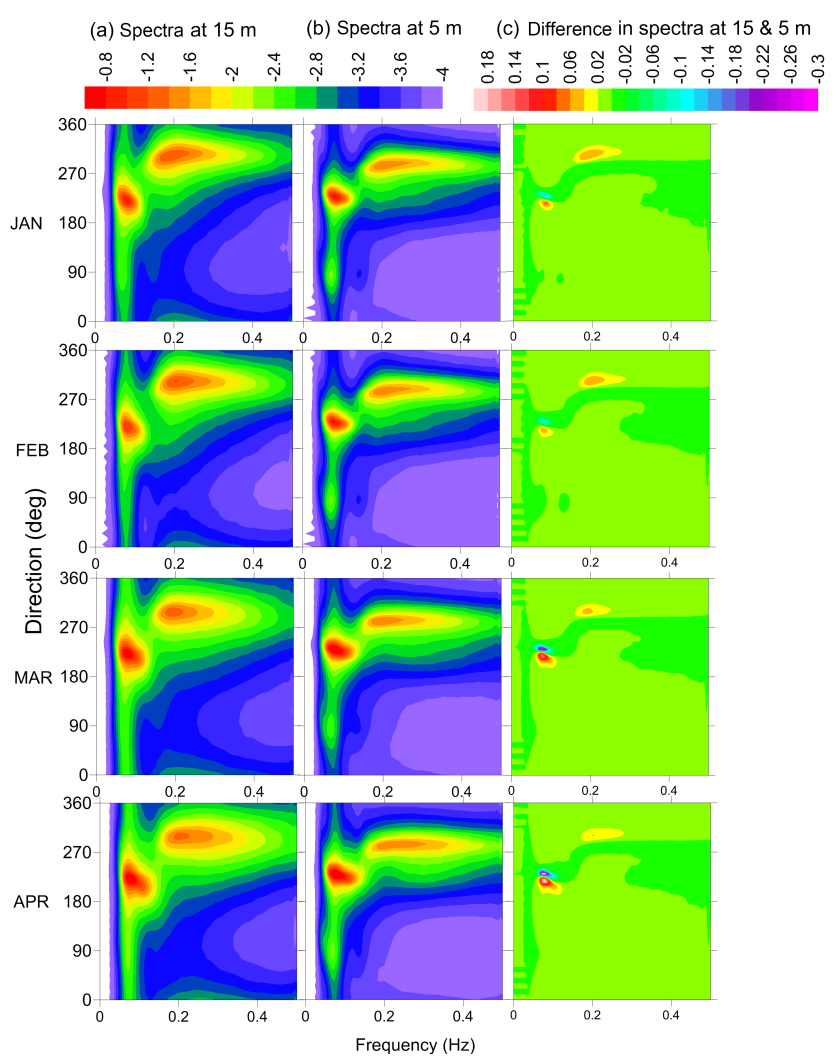

Figure 10. (a) Monthly average directional spectra at $15 \mathrm{~m}$ water depth and (b) at $5 \mathrm{~m}$ water depth. The contours are spectral energy density $\left(\mathrm{m}^{2} \mathrm{~Hz}^{-1}\right)$ in log scale. Plot (c) is the difference in spectral energy at 15 and $5 \mathrm{~m}$ water depth in $\mathrm{m}^{2} \mathrm{~Hz}^{-1}$ degree ${ }^{-1}$.

that the primary peak value of $0.074 \mathrm{~Hz}$ corresponding to the swell is the same for the Ratnagiri location also, but the windsea peak is different since it depends on the local wind condition (Fig. 11a). Sanil Kumar et al. (2014) observed swell peak of the monthly average spectrum at around $0.07 \mathrm{~Hz}$ at Honnavar and Ratnagiri during January to April 2011. In the present study, the mean wave spectrum for frequencies $0.074-0.126 \mathrm{~Hz}$ has a high-frequency tail of $f^{-5}$ (where $f$ is the frequency). For frequencies from 0.229 to $0.58 \mathrm{~Hz}$ at $15 \mathrm{~m}$ water depth, the high-frequency tail has $f^{-2.5}$ and at $5 \mathrm{~m}$ water depth, frequencies from 0.315 to $0.55 \mathrm{~Hz}$ the highfrequency tail has $f^{-3}$ (Fig. 11a). The JONSWAP spectrum has a high-frequency tail of $f^{-5}$ in deep water and the shape evolves to $f^{-3}$ in shallow water (Young and Verhagen, 1996; Holthuijsen, 2007; Gunson and Symonds, 2014). For high waves $\left(H_{\mathrm{m} 0}>2 \mathrm{~m}\right)$, Sanil Kumar and Anjali (2015) observed that the high-frequency part of the spectrum is between the curves proportional to $f^{-4}$ (for frequencies $0.2-0.4 \mathrm{~Hz}$ ) and $f^{-3}$ (for frequencies $0.1-0.2 \mathrm{~Hz}$ ). The 99 and 90 percentile wave spectra are double-peaked and show the predominant peak at 0.071 and $0.073 \mathrm{~Hz}$, and secondary peak at 0.160 and $0.169 \mathrm{~Hz}$ (wind-sea peak) (Fig. 11b). At both locations, the spectral energy is in a wide range of frequencies due to the
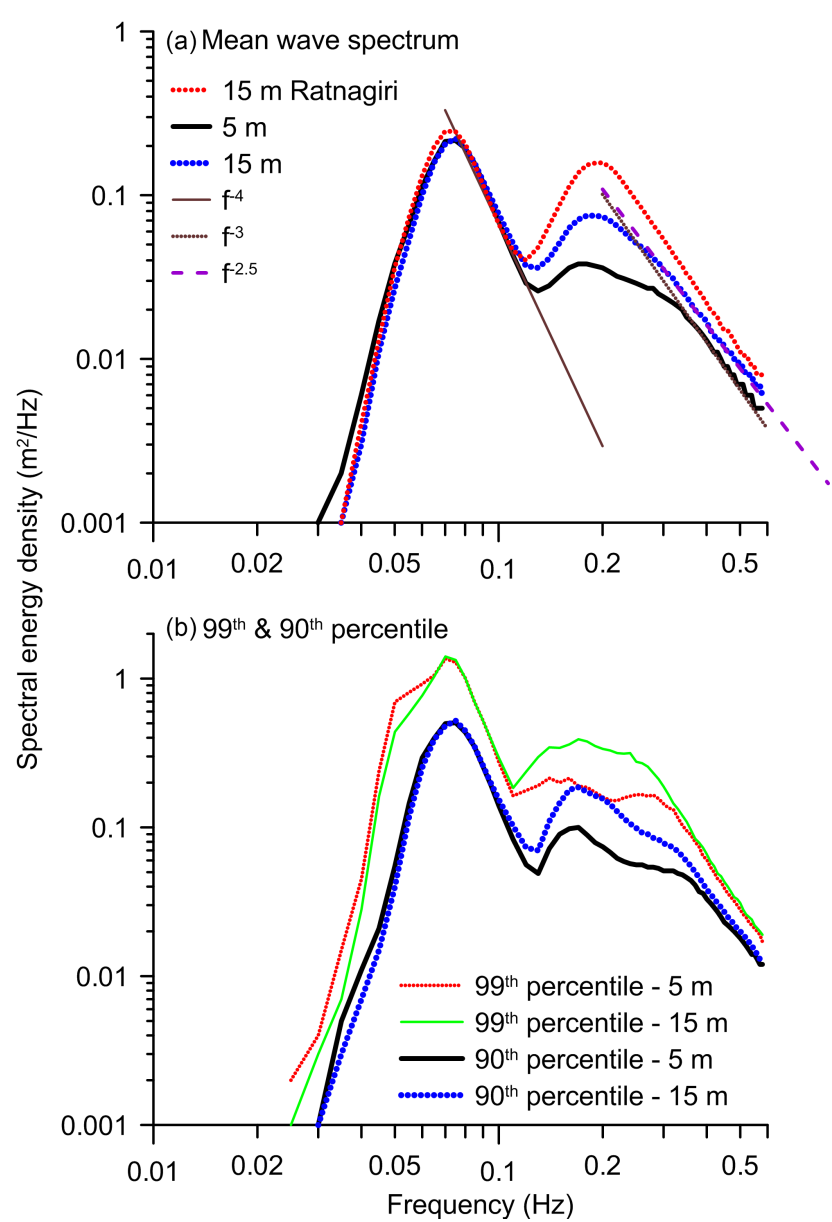

Figure 11. (a) Mean and (b) 90 and 99 percentiles of onedimensional wave energy spectra for the entire study period. Frequency tails are $f^{-4}$ (solid), $f^{-3}$ (dotted) and $f^{-2.5}$ (dashed).

co-existence of wind-seas and swells, and $25.9 \%$ of the total spectral energy is in frequencies $>0.25 \mathrm{~Hz}$ at $15 \mathrm{~m}$ water depth and it is $27.6 \%$ at $5 \mathrm{~m}$ water depth.

As a result of sea breeze, a systematic increase of the highfrequency spectrum of wind waves with increasing wind speed is observed. An analysis of the wind and wave development processes from 12 to 15 February 2015 is presented in Fig. 12. During this time, wind velocities increase from 2 to $6 \mathrm{~m} \mathrm{~s}^{-1}$ then gradually decrease to $2 \mathrm{~m} \mathrm{~s}^{-1}$. The cross-shore component of wind (u-wind) varied from -2 to $4 \mathrm{~m} \mathrm{~s}^{-1}$ and the observed $H_{\mathrm{m} 0}$ at $15 \mathrm{~m}$ water depth varied from 0.4 to $0.8 \mathrm{~m}$. Observed $T_{\mathrm{m} 02}$ increases from 3 to $5 \mathrm{~s}$ then decreases slightly, while peak periods of the windsea part increase from 3 to $7 \mathrm{~s}$ and then decrease indicating that the wave spectrum has experienced substantial frequency down-shifting (Fig. 12). Due to the sea breeze, the spectral peak wave frequency shifts from 0.35 to $0.18 \mathrm{~Hz}$. Off Goa during the onshore phase of the sea breeze, Neetu et al. (2006) observed that the $H_{\mathrm{m} 0}$ of the wind-sea increased with a peak frequency at $0.35 \mathrm{~Hz}$ and then moved to lower 
(a) $15 \mathrm{~m}$ water depth

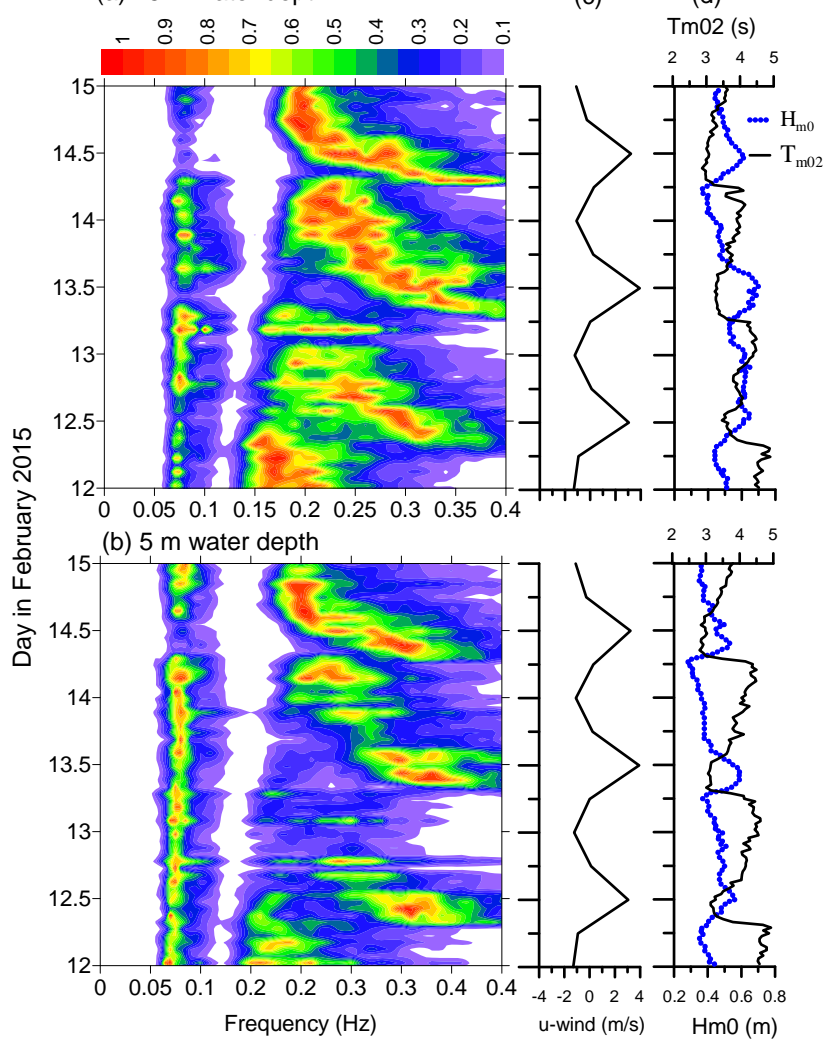

Figure 12. Growth of wave spectrum with sea breeze during 1214 February 2015 (a) at $15 \mathrm{~m}$ water depth and (b) at $5 \mathrm{~m}$ water depth. Swells are also present at both locations. Normalised spectral energy density is presented. Plot (c) is the temporal variation of cross-shore wind (u-wind) and (d) is temporal variation of significant wave height and mean wave period.

frequencies $(\sim 0.15 \mathrm{~Hz})$ (Neetu et al., 2006). The in situ measurements off Vengurla over several sea-breeze cycles shows that the wind-sea growth starts at 09:00 UTC with the increase in spectral energy at frequencies 0.45 to $0.58 \mathrm{~Hz}$. At 12:00 UTC, the increase in spectral energy is observed at frequencies 0.4 to $0.5 \mathrm{~Hz}$, and by 15:00 UTC the increase in spectral energy is at 0.25 to $0.4 \mathrm{~Hz}$. To examine the change in wave spectrum due to the sea breeze, the monthly averaged wave spectra at 05:00, 13:00 and 15:00 UTC are compared at 5 and $15 \mathrm{~m}$ water depth (Fig. 13). The spectral energy of the wind-sea part increased at 13:00 and 15:00 UTC compared to 05:00 UTC and the increase is similar at 5 and $15 \mathrm{~m}$ water depth. During February, the swell-dominated spectrum changed to a wind-sea-dominated spectrum at the peak of the sea breeze and hence the average wave spectrum has predominant wind-sea peak at 15:00 UTC. The energy in the windsea part dissipates when the waves travel from $15 \mathrm{~m}$ water depth to $5 \mathrm{~m}$, but the low-frequency (swell) part of the wave spectrum is similar at 5 and $15 \mathrm{~m}$ water depth during both the 05:00 and 13:00 UTC. The intensification of wind-sea at $15 \mathrm{~m}$ water depth compared to $5 \mathrm{~m}$ water depth is more at
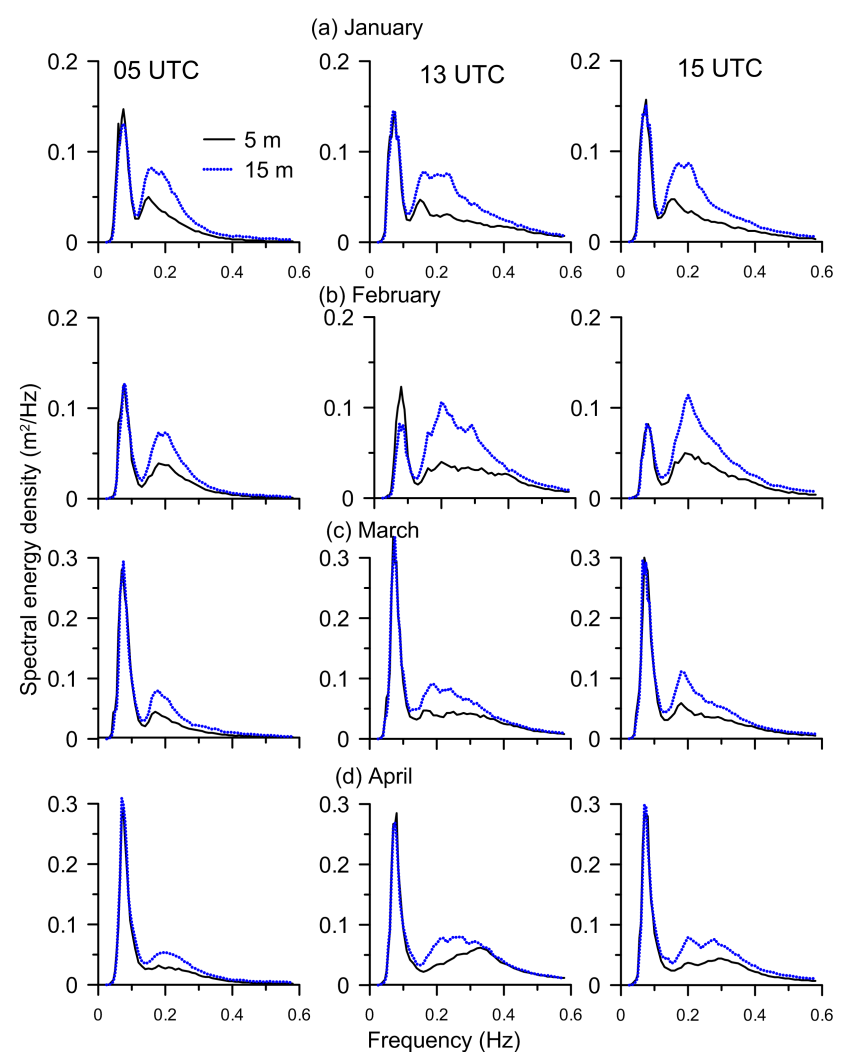

Figure 13. Monthly average wave spectrum at 05:00, 13:00 and 15:00 UTC during January-April at 5 and $15 \mathrm{~m}$ water depth.

13:00 UTC compared to 05:00 UTC. Through laboratory experiments, Mitsuyasu (1992) has shown that wind-sea is intensified by an opposed swell and hence the intensification of wind-sea at $15 \mathrm{~m}$ water depth is due to the result of reflected swells and the sea-breeze-induced wind-sea.

\section{Conclusions}

The analysis of wave observations at 5 and $15 \mathrm{~m}$ water depth is conducted based on data measured off Vengurla, India from 1 January to 30 April 2015. The variation of peak wave period in 1 day is high $(\sim 8 \mathrm{~s})$ due to the influence of land/sea breezes. Prior to the sea breeze, the wave field is dominated by swell $\left(T_{\mathrm{p}}>10 \mathrm{~s}\right)$ and during the sea breeze, wind-sea $\left(T_{\mathrm{p}}<5 \mathrm{~s}\right)$ dominates with superimposed swell. The mean wave spectrum shows the predominant swell peak at $0.074 \mathrm{~Hz}$ both at 15 and $5 \mathrm{~m}$ water depth, but the wind-sea peak is shifting from 0.187 to $0.174 \mathrm{~Hz}$ when the waves travel from 15 to $5 \mathrm{~m}$ water depth. Due to the sea breeze, the intensification of wind-sea is more at $15 \mathrm{~m}$ compared to that at $5 \mathrm{~m}$ water depth. The wind-sea part of the wave spectrum dissipates when waves travel from 15 to $5 \mathrm{~m}$ water depth resulting in more $(90 \%)$ swell-dominated spectra at $5 \mathrm{~m}$ than at $15 \mathrm{~m}$ water depth $(78 \%)$. 
Acknowledgements. The authors acknowledge the Council of Scientific and Industrial Research, New Delhi and Earth System Science Organization, Ministry of Earth Sciences, New Delhi for providing the financial support to conduct this research. The Director, CSIR-NIO, Goa provided facilities to carry out the study. We thank R. S. Kankara, Head, Coastal Processes and Shoreline Management, ICMAM- PD, Chennai for support during data collection. This is NIO contribution no. 5860.

The topical editor, V. Kotron, thanks three anonymous referees for help in evaluating this paper.

\section{References}

Aboobacker, V. M., Seemanth, M., Samiksha, S. V., Sudheesh, K., Jyoti, K., and Vethamony, P.: Sea breeze-induced wind sea growth in the central west coast of India, Ocean Eng., 84, 20-28, 2014.

Aboobacker, V. M., Vethamony, P., Samiksha, S. V., Rashmi, R., and Jyoti, K.: Wave transformation and attenuation along the west coast of India: Measurements and numerical simulations, Coast. Eng. J., 55, 1350001-1350022, 2013.

Amrutha, M. M. and Sanil Kumar, V.: Short-term statistics of waves measured off Ratnagiri, eastern Arabian Sea, Appl. Ocean Res., 53, 218-227, doi:10.1016/j.apor.2015.09.009, 2015.

Amrutha, M. M., Sanil Kumar, V., Sheela, S., Singh, J., Gowthaman, R., and Kankara, R. S.: Characteristics of shallow water waves off the central west coast of India before, during and after the onset of the Indian summer monsoon, Ocean Eng., 107, 259-270, doi:10.1016/j.oceaneng.2015.07.061, 2015.

Anoop, T. R., Sanil Kumar, V., and Shanas, P. R.: Spatial and temporal variation of surface waves in shallow waters along eastern Arabian Sea, Ocean Eng., 81, 150-157, doi:10.1016/j.oceaneng.2014.02.010, 2014.

Anoop, T. R., Sanil Kumar, V., Shanas, P. R., and Johnson, G.: Surface wave climatology and its variability in the North Indian Ocean based on ERA-Interim reanalysis, J. Atmos. Ocean. Tech., 32, 1372-1385, doi:10.1175/JTECH-D-14-00212.1, 2015.

Aparna, M., Shetye, S. R., Shankar, D., Shenoi, S. S. C., Mehra, P., and Desai, R. G. P.: Estimating the seaward extent of sea breeze from QuikSCAT scatterometry, Geophys. Res. Lett., 32, L13601, doi:10.1029/2005GL023107, 2005.

Ardhuin, F., O'Reilly, W. C., Herbers, T. H. C., and Jessen, P. F.: Swell transformation across the continental shelf - Part I: Attenuation and directional broadening, J. Phys. Oceanogr., 33, 19211939, 2003.

Baba, M., Dattatri, J., and Abraham, S.: Ocean wave spectra off Cochin, west coast of India, Indian J. Mar. Sci., 18, 106-112, 1989.

Battjes, J. A. and Stive, M. J. F.: Calibration and verification of a dissipation model for random breaking waves, J. Geophys. Res., 90, 9159-9167, 1985.

Battjes, J. A. and Janssen, J. P. F. M.: Energy loss and set-up due to breaking of random waves, Proceedings 16 International Conference in Coastal Engineering, ASCE, 569-587, 1978.

Booij, N., Ris, R. C., and Holthuijsen, L. H.: A third generation wave model for coastal regions. Model description and validation, J. Geophys. Res., 104, 7649-7666, 1999.
Dee, D. P.: The ERA-Interim reanalysis: Configuration and performance of the data assimilation system, Q. J. Roy. Meteor. Soc., 137, 553-597, 2011.

Dora, G. U. and Sanil Kumar, V.: Sea state observation in islandsheltered nearshore zone based on in situ intermediate-water wave measurements and NCEP/CFSR wind data, Ocean Dynam., 65, 647-663, doi:10.1007/s10236-015-0822-1, 2015.

Glejin, J., Sanil Kumar, V., Nair, T. N. B., and Singh, J.: Influence of winds on temporally varying short and long period gravity waves in the nearshore regions of the eastern Arabian Sea, Ocean Sci., 9, 343-353, 2013.

Gunson, J. and Symonds, G.: Spectral Evolution of Nearshore Wave Energy during a Sea-Breeze Cycle, J. Phys. Ocean., 44, 31953208, 2014.

Hanson, J. L. and Phillips, O. M.: Automated analysis of ocean surface directional wave spectra, J. Atmos. Oceanic. Technol., 18, 277-293, 2001.

Hasselmann, K., Barnett, T. P., Bouws, E., Carlson, H., Cartwright, D. E., Enke, K., Ewing, J. A., Gienapp, H., Hasselmann, D. E., Kruseman, P., Meerbrug, A., Muller, P., Olbers, D. J. Richter, K. Sell, W., and Walden, H.: Measurements of wind- wave growth and swell decay during the Joint North Sea Wave Project (JONSWAP), Deutsche Hydrographische Zeitschrift, A80, 95 pp., 1973.

Holthuijsen, L. H.: Waves in Oceanic and Coastal Waters, Cambridge University Press, ISBN-13, 978-0521129954, 404 pp., 2007.

Kinsman, B.: Wind Waves, Their Generation and Propagation on the Ocean Surface, Prentice-Hall, 676 pp., 1965.

Kuik, A. J., Vledder, G., and Holthuijsen, L. H.: A method for the routine analysis of pitch and roll buoy wave data, J. Phys. Oceanogr., 18, 1020-1034, 1988.

Miller, S. T. K., Keim, B. D., Talbot, R. W., and Mao, H.: Sea breeze: Structure, forecasting, and impacts, Rev. Geophys., 41, 1011, doi:10.1029/2003RG000124, 2003.

Mitsuyasu, H.: Wave breaking in the presence of wind drift and opposed swell, in: Breaking Waves, edited by: Banner, M. L. and Grimshaw, R. H. J., Springer Verlag, 147-153, 1992.

Neetu, S., Shetye, S. R., and Chandramohan, P.: Impact of seabreeze on wind-seas off Goa, west coast of India, J. Earth Syst. Sci., 115, 229-234, doi:10.1007/BF02702036, 2006.

NHO: India-West coast: Malvan to Coondapoor, Hydrographic chart no. 257, Published at the National Hydrographic Office, Dehradun, India, 2004.

Pattiaratchi, C., Hegge, B., Gould, J., and Eliot E.: Impact of sea breeze activity on nearshore and foreshore processes in southwestern Australia, Cont. Shelf Res., 17, 1539-1560, 1997.

Pierson, W. J. and Moskowitz, L.: A proposed form for fully developed seas based on the similarity theory of S. A. Kitaigorodski, J. Geophys. Res., 69, 5181-5190, 1964.

Portilla, J., Ocampo-Torres, F. J., and Monbaliu, J.: Spectral Partitioning and Identification of Wind Sea and Swell, J. Atmos. Ocean Tech., 26, 117-122, 2009.

Ris, R. C., Booij, N., and Holthuijsen, L. H.: A third- generation wave model for coastal regions - Part II: verification, J. Geophy. Res., 104, 7649-7666, 1998.

Sanil Kumar, V. and Anjali Nair, M.: Inter-annual variations in wave spectral characteristics at a location off the central west coast of 
India, Ann. Geophys., 33, 159-167, doi:10.5194/angeo-33-1592015, 2015.

Sanil Kumar, V., Anand, N. M., Kumar, K. A., and Mandal, S.: Multipeakedness and groupiness of shallow water waves along Indian coast, J. Coastal. Res., 19, 1052-1065, 2003.

Sanil Kumar, V., Kumar, K. A., Pednekar, P., and Gowthaman, R.: Sea and swell along west coast of India: study based on measured data, Proceedings Fourth Indian National Conference on Harbour and Ocean Engineering (INCHOE-07), NIT Surathkal, India, 736-745, 2007.

Sanil Kumar, V., Johnson, G., Dora, G. U., Philip, S. C., Singh, J., and Pednekar, P.: Variations in nearshore waves along Karnataka, west coast of India, J. Earth. Syst. Sci., 121, 393-403, 2012.

Sanil Kumar, V. S., Shanas, P. R., and Dubhashi, K. K.: Shallow water wave spectral characteristics along the eastern Arabian Sea, Nat. Hazards, 70, 377-394, doi:10.1007/s11069-013-08157, 2014.
Semedo, A., Sušelj, K., Rutgersson, A., and Sterl, A.: A global view on the wind sea and swell climate and variability from ERA-40, J. Clim., 24, 1461-1479, 2011.

Soares, C. G.: On the occurrence of double peaked wave spectra, Ocean Eng., 18, 167-171, 1991.

Vethamony, P., Aboobacker, V. M., Menon, H. B., AshokKumar, K., and Cavaleri, L.: Super imposition of wind seas on pre-existing swells off Goa coast, J. Mar. Syst., 87, 47-54, 2011.

WL Delft Hydraulics: Delft3D-Wave User Manual, Delft, the Netherlands, 2011.

Young, I. R. and Verhagen, L. A.: The growth of fetch limited waves in water of finite depth - Part I: Total energy and peak frequency, Coastal Eng., 29, 47-78, 1996. 